Citation: Izwaini, S. \& Al-Omar, H. (2019). The translation of substitution and ellipsis in Arabic subtitling. Journal of Audiovisual Translation, 2(1), 126-151.

Editor(s): J-L. Kruger \& A. Jankowska

Received: October 11, 2018

Accepted: January 31, 2019

Published: November 30, 2019

Copyright: (C2019 Izwaini \& Al-Omar. This is an open access article distributed under the terms of the Creative Commons Attribution License. This allows for unrestricted use, distribution, and reproduction in any medium, provided the original author and source are credited.

\section{The Translation of Substitution and Ellipsis in Arabic Subtitling}

\author{
Sattar Izwaini
}

Dept. of Arabic and Translation Studies

American University of Sharjah, UAE

\author{
Hafsa Al-Omar ${ }^{\bowtie}$ \\ Urban Planning Sector \\ Department of Urban Planning and Municipalities, UAE
}

\begin{abstract}
This paper investigates the trends in translating cohesive devices while subtitling English-speaking films into Arabic through examining a corpus of 20 films. It looks at how translators deal in particular with substitution and ellipsis and how their approaches serve the cohesiveness of the subtitles. The paper also looks at the translation shifts resulting from those approaches. The study is based on Halliday and Hasan's model of cohesion (1976). The analysis has found a considerable number of shifts occurring while dealing with the cohesion of the target texts. Repetition stands to be the most dominant cohesive tie that is used as a counterpart of substitution and ellipsis in the English originals, making explicitation the main strategy in translating such ties in Arabic subtitles. Substitution comes second while ellipsis and reference are found to be marginal. In their tendency to avoid ellipsis, translators opt for repetition or substitution as cohesive devices in Arabic subtitles.
\end{abstract}

Key words: Arabic subtitling, cohesion, ellipsis, substitution, translation shifts. 


\section{Introduction}

Cohesion refers to the overt inter-sentential relationships and it occurs when the text is connected together by means of linguistic and semantic markers. It "occurs where the interpretation of some elements in the text is dependent on that of another. The one presupposes the other, in the sense that it cannot be effectively decoded except by recourse to it" (Halliday \& Hasan, 1976, p. 4). De Beaugrande (1980) argues that cohesion includes "the procedures whereby surface elements appear as progressive occurrences that their sequential connectivity is maintained and recoverable" (p. 19). Baker (1992) defines cohesion as the network of lexical, grammatical, and other relations which provide links between various parts of a text, for instance by requiring the reader to interpret words and expressions by reference to other words and expressions in the surrounding sentences and paragraphs (p. 180).

The present paper investigates cohesion in Arabic subtitles. The analysis is based on Halliday and Hasan's model of cohesion in English (1976). According to Brown and Yule (1983), this model "is by far the most comprehensive treatment of the subject and has become the standard text in this area" (p. 190). In discussing cohesion within textual equivalence, Baker (1992) describes Halliday and Hasan's model as "the best known and the most detailed model of cohesion available" (p. 180).

According to Halliday and Hasan, cohesion is a semantic relation realized through the lexicogrammatical system. Their approach to cohesion is based greatly on the concept of tie. According to their model, cohesion is a relation that occurs between two lexical items referred to as members. This leads to the conclusion of the intricacy of cohesion, as any sentence may have more than one tie and the presupposed item can be identified through an immediate cohesive element.

Halliday and Hasan propose two main categories of cohesion with six subcategories: grammatical cohesion (substitution, ellipsis, reference, conjunction), and lexical cohesion (collocation and reiteration). The current paper focuses on substitution and ellipsis.

This study examines cohesion as a phenomenon in subtitled texts. By investigating cohesion in subtitling, the study attempts to contribute to a less-researched area of audiovisual translation. It provides an analysis of examples of substitution and ellipsis in the source text (ST) and the way translators deal with these cohesive devices in the target text (TT). The analysis aims at offering insight about the trends prevailing when translating into Arabic subtitles.

The main research questions are: how have substitution and ellipsis been changed in Arabic subtitling?; what are the translation strategies employed by translators in dealing with these two cohesive devices?; and what are the main trends of translating substitution and ellipsis in Arabic subtitling? 


\section{Substitution and Ellipsis in English}

Substitution is the relation between elements such as words or phrases; "since substitution is a grammatical relation [...] the substitute may function as a noun, as a verb, or as a clause" (Halliday \& Hasan, 1976, p. 90). There are three types of substitution: nominal, verbal, and clausal.

1. Nominal substitution means having the substitute one and the plural ones function as the head in the nominal group, and can substitute only an item that is itself the head of a nominal group: Your phone is obsolete. You must get a new one.

2. Verbal substitution takes place when the verb do or does substitutes a lexical verb functioning as the head of the verbal group, and its position would be final as in: (a) Shall I make the announcement? (b) You can do now (Halliday \& Hasan, 1976, p. 116).

3. Clausal substitution occurs when the clausal substitute so and the negative form not operate on the entire clause, i.e., they presuppose the entire clause not just a noun or a verb:

(1) A. Are you attending the symposium? B. I think so.

C. Is it going to rain today? D. I hope not.

Ellipsis is normally an anaphoric relation like substitution. It is a relation within the text, and the presupposed item is present in the preceding text. Halliday and Hasan distinguish between three types of ellipsis: nominal, verbal, and clausal.

1. Nominal ellipsis takes place when the head of a nominal group is omitted. The function of the head is taken by one of the other elements (deictic, numerative, epithet, or classifier), e.g. Would you like to take this card? I have two more. The head of the nominal group, card, is omitted with the numerative two functioning as a head.

2. Verbal ellipsis operates in the verbal group, and when it takes place, the structure does not express its systemic features fully; it necessitates to be recovered by presupposition. For example, in Joan brought some carnations and Catherine some sweet peas (Halliday \& Hasan, 1976, p. 143), the structure of the second clause lacks a verb. This verb is presupposed to be provided by the preceding clause. 
There are two types of verbal ellipsis: lexical ellipsis and operator ellipsis. Any verbal group that does not contain a lexical verb is elliptical:

(2) A. Is he going to come? B. He might.

In the above example, the verbal item might is an elliptical verbal group. In order to fill out the verbal group, a lexical verb needs to be presupposed from the previous utterance.

Operator ellipsis, on the other hand, involves the omission of the operator: A. What have you been doing? B. Reading. In the answer to the question, the operator which can be recovered by supposition is omitted. This kind of ellipsis occurs across sentences, characterized by very closely bonded sequences such as a question and answer, in which the lexical verb either supplies the answer, as above, or repudiates the verb in the question: A. Has she been singing? B. No, dancing.

3. Clausal ellipsis is looking at verbal ellipsis from the clausal point of view where either one of the two clausal elements of modal and proposition is omitted (see Halliday \& Hasan, 1976, pp. 197-198), e.g. The governor is going to set up a follow-up committee where 'the governor is' is the modal element and going to set up a follow-up committee is the proposition. In the two conversations below clausal ellipsis occurs by omitting either element:

(3) A. What is the Governor going to do? B. Setting up a committee.

C. Who is going to set up a committee? D. The Governor is.

There are special features of both substitution and ellipsis that require some attention here: finiteness, polarity and modality. These pertain to the presuppositions on which these two cohesive devices are based. In terms of finiteness, the categorization of operators are to be finite or non-finite. If finite, then an operator is indicative or imperative. If indicative, it can be a modal or non-modal (Halliday \& Hasan, 1976, p. 167). In lexical ellipsis, the polarity has to be made explicit and the first operator is always present whatever else is deleted; the finite operator is never omitted (Halliday \& Hasan, 1976, pp. 167, 176, 177, 181).

On the other hand, polarity refers to whether the statement is positive or negative, and marked or unmarked (Halliday \& Hasan, 1976, p. 167), whereas modality is "the speaker's assessment of the probabilities inherent in the situation, or the rights and duties" (Halliday \& Hasan, 1976, p. 135).

\section{Substitution and Ellipsis in Arabic}

In Arabic, cohesion is dealt with as one area of the field of علم المعاني 'ilm al-ma ānì (literally the science of meanings). This field focuses on the semantics of different processes and how thoughts 
are expressed. Al-Jurjāny (died in $471 \mathrm{AH} / 1078 \mathrm{AD}$ ) is the founder of 'ilm al-ma'āni through his theory of النظم al-naẓm (organization of discourse). Al-Jurjāny's theory is a fully-fledged account of cohesion in Arabic. It is a paradigm of the semantics of syntactic structures to achieve the intended meaning. It deals with how to compose a text to establish cohesion and coherence through interrelating text elements by having lexico-grammatical functions therein (Al-Jurjāny 2004, pp. 100, 103). Al-Jurjāny classifies meaning into two types: semantic and syntactic, and naẓm implies that word meanings are organized according to the syntactic order. Naẓm is essentially the eloquent formulation of textual elements by relating them one to another in a way that interconnects them semantically. It is attaining stylistic elegance via rhetorical structuring.

Substitution in Arabic is looked at as a cohesive link that refers to a word or phrase that substitutes elements in the same grammatical slot elsewhere in the text: طلبتْ قطع صلته بها أياما ففعل (she asked him to sever his relation with her few days so he did). The verb فعل (did) substitutes the phrase of 'to sever his relation with her some days'. The substituting verb may be supported by a demonstrative: (أمره أن يغني، ففعل ذلك (he commanded him to sing, so he did that). However, the word ذلك (that) in the example below substitutes the phrase أن تفوز

(4) هل تتوقع أن يفوز؟ (do you expect him to win?)

$$
\text { نعم، أتوقع ذلك (yes I expect that) }
$$

It is worth noting that ذلك (that) does not function here as demonstrative pronoun as such, but rather as a cohesive device presupposing what is discussed. It connects the two sentences together by providing an interpretation of the reply.

Ellipsis in Arabic is treated under the umbrella of الإيجاز (brevity). Different elements of the sentence could be omitted depending on the presence of an element in the cotext (an index) that helps the hearer/reader understand the sentence. Due to the scope of the article, the restriction on word count and the detailed categories of ellipsis in Arabic, only a brief account will be given here.

According to Hammudah (1998, p. 20), Sībawayh used the terms حذف hadff (ellipsis) and إضمار 'idmār (concealment) interchangeably. Al-Sakkāky (1987, pp. 176, 206, 224-225, 228) maintains that ellipsis can be based on the receiver's clear understanding of the message, with the help of the cotext and context as well as non-textual elements. The purpose of ellipsis can be euphemism, willingness to be implicit, or brevity. Hassan states that ellipsis in Arabic always occurs when there is a cotext element (index) that disambiguates the elliptic one (1979, p. 218). In the example below the verb in the coordinated clause is omitted depending on the one in the first clause (Hassan, 1979, p. 219):

(5) إن زيدا هلك أو كاد (Zeid perished or was about to). 
Subordinate clauses could be omitted when disambiguation is guaranteed, i.e., when other sentence elements are sufficient for interpretation (Hassan, 1979, pp. 220-221). This includes the second part of conditional sentences and answers of questions, e.g.

(6) من جاء؟ (who came?)

$$
\text { علي (Ali) }
$$

One of the structures in which omission occurs is the case of coordination, as in the Qur'anic verse أكلها دائم وظلها (its fruit is eternal and its shade is) (13:35, Al-Ra'd). Here, the assumed structure of the sentence is أكلها دائم وظلها دائم (its fruit is eternal and its shade is eternal), but the predicate of the second clause is ellipted to avoid repetition of the predicate of the first clause.

Ellipsis necessitates acceptability of structure, presence of an index element and possibility of recovering the ellipted item. It includes among other things, pronominals omitted for economy, verb of quoting and reporting speech قال (to say), transitive verbs with the object omitted making it generic and comprehensive, e.g. يأمر وينهى (to command and prohibit).

The cohesive devices in both Arabic and English are not fully compatible when it comes to features of both substitution and ellipsis such as finiteness, polarity and modality. For example, non-finite operators may be substituted or ellipted, which is not necessarily the case in a corresponding structure in Arabic. This can be a good reason why translators opt to change the cohesive device in subtitling.

\section{Cohesion in Subtitling}

Diaz-Cintas and Remael (2007) define subtitling as "a translation practice that consists of presenting a written text... that endeavors to recount the original dialogue of the speakers, as well as discursive elements that appear in the image, and the information that is contained on the soundtrack" (p. 8). Subtitles are a condensed version of the target text incorporated on the screen, and they have to be as short as possible to help the audience to read and process them within a relatively short time (Chiaro, 2009, p. 148). Subtitles express what is said (spoken medium) into a written text to be read (written medium).

De Linde and Kay (1999, pp. 28-31) discuss the different cohesive devices used to achieve text cohesion. They maintain that these devices do not only establish cohesion in subtitles, but they also enhance the text readability. According to them, not reproducing the cohesive relations in subtitling "can lead to a text becoming more difficult to process and result in loss of meaning" $(1999$, p. 30).

Cohesion does not only establish a text unity, but it also helps the audience process and understand the textual elements, as these are an integral part of the semiotic whole, thus providing coherence 
through intertextuality between the verbal communication and other semiotic elements, i.e., the visual. Lack of cohesion in subtitles can be further complicated by their transitory nature and relation to visual elements (De Linde \& Kay, 1999, p. 30). Subtitling should benefit much from cohesive ties such as reference and ellipsis to produce condensed translations.

Cohesive subtitles are constructed by bearing in mind semiotic resources, i.e., linguistic and nonlinguistic that are available in a screen production. Linguistic resources can be manipulated to meet the needs of the target audience. Subtitlers will have to select key and relevant elements that will be transposed into the subtitles and that will assist in the construction of meaning in the target language. Semiotic elements in a screen production can help in establishing cohesion and coherence. The focus of this study, however, is on the linguistic elements of a spoken discourse as it is the overwhelming majority of discourse in feature films.

Subtitling involves processes such as elimination, condensation and reformulation, which can lead to shifts in translation. Shifts are changes that take place in translation. They are the results of the translator's attempts to deal with the differences between the ST and the TT (Bakker, Koster, \& Van Leuven-Zwart, 1998). Catford (1965) defines shifts as "departures from formal correspondence in the process of going from the SL to TL" (p. 73). Furthermore, space and linguistic constraints have their say in how subtitles are formulated (see Gottlieb, 1998).

\section{Data and Methodology}

This paper sheds light on the strategies employed in dealing with cohesive devices, namely substitution and ellipsis, when producing Arabic subtitles. The examples are taken from a corpus of 20 English-speaking films of different genres. The films are either broadcast by TV stations such as Dubai One, Fox Movies and $\mathrm{MBC2}$, or viewed on DVDs produced and translated by different production companies. TV channels normally outsource subtitling assignments to regional agencies in Egypt, Jordan, Lebanon and the United Arab Emirates (UAE). The selection criteria of the corpus are mainly availability as well as diversity of genre, year of production, country of origin and a need for balanced representation of works subtitled by individual translation agencies.

In our data, there are 19 occurrences of substitution (seven cases of nominal substitutions, eight of verbal substitutions and four of clausal substitutions) and 17 occurrences of ellipsis (six instances of nominal ellipsis, six of verbal ellipsis and five of clausal ellipsis).

The present study will focus only on the linguistic component of the ST semiotics. Therefore, visual and acoustic elements will not be considered here. Moreover, as the text in subtitles tends to be fragmented in sentences that are transitory in nature, i.e., they appear and disappear on the screen, cohesion is examined here at sentence level only (within the boundaries of two lines of subtitling). 
The subtitles will be compared to the original and any change in the cohesive elements will be discussed. The graph below illustrates how this is looked at. The translation of what is substituted in the ST, for example, is rendered the same, repeated or deleted in the TT.

Figure 1.

How the Translation of Substitution and Ellipsis Are Examined Within the Arabic Subtitles

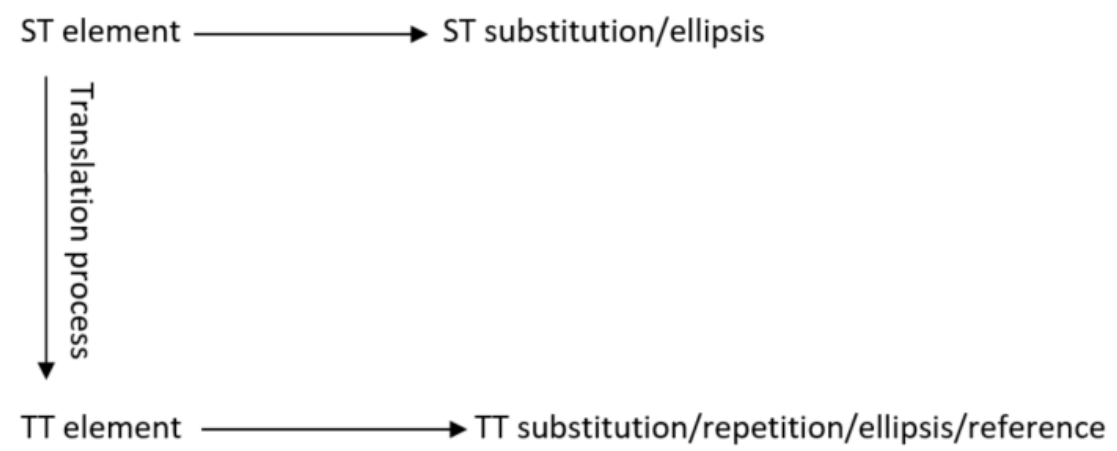

While Halliday and Hasan's model does not readily apply in its entirety to Arabic, any observed shifts involving cohesive devices are not necessarily indicative of an optional subtitling strategy. The TL system and style usually guide translators to produce a cohesive text, thus opting for this or that strategy.

The analysis will look at how effective Arabic subtitles are at achieving cohesion either by maintaining the cohesive device of the ST or shifting to another device. Shifts will be analysed to see whether they are justified or not, and whether they contribute to the cohesiveness of the subtitles.

\section{Discussion and Analysis}

No doubt that the differences between language systems necessitate shifts in dealing with textual aspects. Transferring ST cohesive devices in translation will not do without reworking them to establish links that suit the TL norms. What matters is the preference of TL cohesive devices and the role of the translator in establishing linkage suitable for the norms acceptable in the TL. This can entail changing the cohesive devices of the ST.

The aim of the translator is presumably to achieve cohesion in the translation with devices available in the TL, bearing in mind the preference of the TL in terms of cohesion (i.e., what is appropriate to the language system and the style that establishes cohesion in the TT). Translators deploy different procedures in Arabic subtitles in order to achieve cohesion. These will be discussed in detail below. Based on our statistics, it has been found that a considerable number of shifts (lexical and grammatical) were made in the ST cohesive devices within the translation process. To provide 
an overview of the devices used in subtitles and shifts occurred, we present figures and a table of statistics below.

As we can see in Figure 2, six occurrences of nominal substitution are shifted into repetition (85.7\%) and one occurrence is translated as nominal substitution (14.29\%). For verbal substitution, six occurrences $(75 \%)$ are rendered as repetition, while one occurrence $(12.5 \%)$ is translated into nominal substitution and one (12.5\%) into verbal substitution. With regard to clausal substitution, three occurrences (75\%) are rendered as clausal substitution whereas one occurrence thereof (25\%) slightly shifts into verbal substitution.

Figure 2.

Translation of ST Substitutions in Arabic Subtitles.

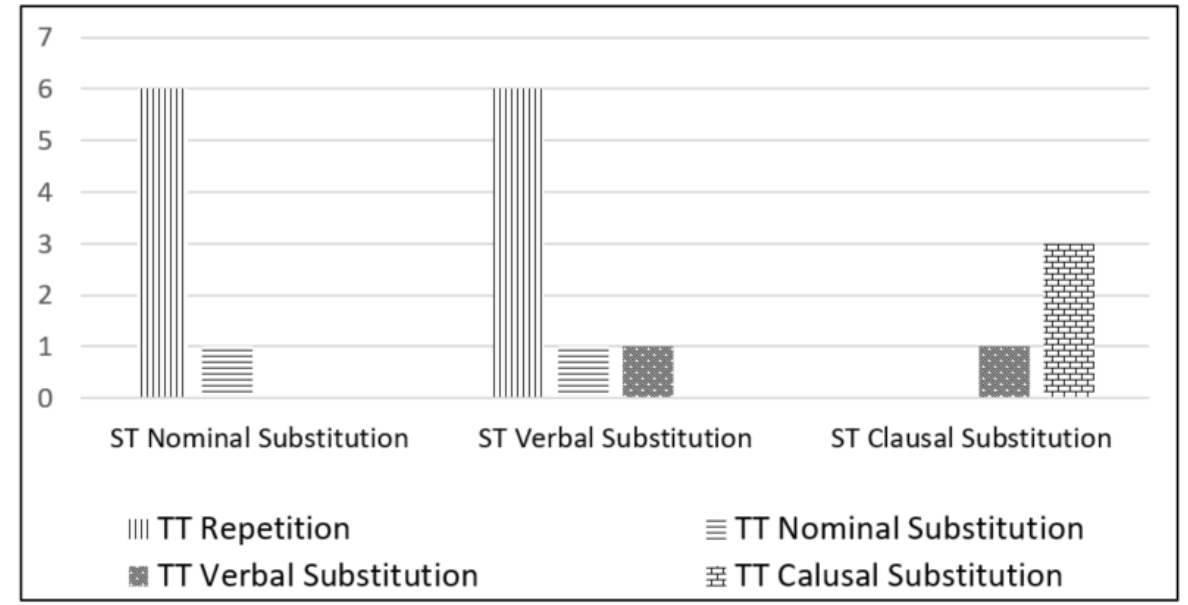

For ellipsis, Figure 3 shows that three occurrences of nominal ellipsis (50\%) are translated as nominal substitution, two occurrences (33.33\%) are recovered as repetition, and one occurrence (16.67\%) shifts into reference in the TT. We also notice that repetition is the dominant cohesive device in translating verbal ellipsis with four occurrences (66.67\%), while two occurrences (33.33\%) are rendered as verbal substitution. For clausal ellipsis, three occurrences (60\%) are recovered as clausal substitution and two (40\%) are translated as clausal ellipsis. 
Figure 3.

Translation of ST Ellipsis in Arabic Subtitles

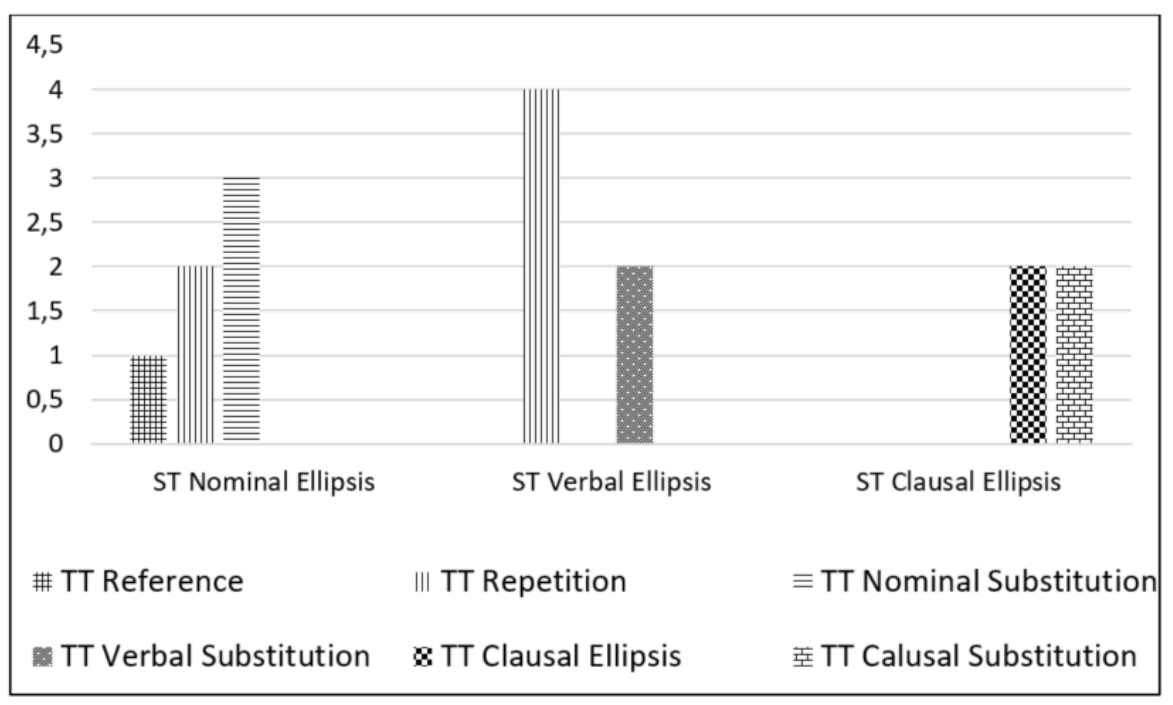

As we can gather form Figures 2 and 3 above and Table 1 below, repetition is predominantly used in translating cohesive devices in Arabic subtitles, in particular in the translation of nominal substitution and verbal substitution as well as verbal ellipsis and nominal ellipsis. Second comes substitution, mainly in rendering clausal ellipsis as well as nominal and clausal substitutions. Ellipsis and reference are marginal. The former is solely used in the translation of clausal ellipsis and the latter in dealing with one case of nominal ellipsis.

Table 1 below shows that in terms of shifts taking place as a result of opting for these devices in the Arabic subtitles, seven cases of substitution are retained as such (36.84\%), whereas making shift by using repetition in dealing with this particular device accounts for about $63.15 \%$. So in dealing with substitution, explicitation by repetition is much more commonly applied than retaining substitution.

As for ellipsis, two occurrences (11.77\%) are translated into ellipsis, whereas shifts occur in dealing with this device account for about $88.23 \%$. As a whole, non-shift renditions combined are $25 \%$ $(7+2$ out of 36$)$ making the percentage of shifts in dealing with both devices of ellipsis and substitution $75 \%(18+8+1$ out of 36$)$. 
Table 1.

Numbers and Percentages of Cohesive Devices in Arabic Subtitles Used to Translate Those in English STs

Cohesive devices in STs

\begin{tabular}{cccccc}
\hline \multicolumn{2}{c}{ Substitution (19) } & \multicolumn{2}{c}{ Ellipsis (17) } & \multicolumn{2}{c}{ Total (36) } \\
$\begin{array}{c}\text { No. of } \\
\text { occurrences }\end{array}$ & $\%$ & $\begin{array}{c}\text { No. of } \\
\text { occurrences }\end{array}$ & $\%$ & $\begin{array}{c}\text { No. of } \\
\text { occurrences }\end{array}$ & $\%$ \\
\hline 12 & $63.15 \%$ & 6 & $35.3 \%$ & 18 & $50 \%$ \\
7 & $36.84 \%$ & 8 & $47 \%$ & 15 & $41.6 \%$ \\
0 & $0 \%$ & 2 & $11.7 \%$ & 2 & $5.5 \%$ \\
0 & $0 \%$ & 1 & $5.88 \%$ & 1 & $2.77 \%$ \\
\hline
\end{tabular}

While constraints of time and space play a significant role in the reduction of the text in subtitling, (see Gottlieb, 1998, p. 247), subtitling into Arabic seems, nevertheless, to consider the cohesion requirements of the TL. Arabic style favours repetition, especially in dealing with SL cohesive devices such as substitution and ellipsis. Johnstone (1991, p. 71) contends that "English discourse rules (codified in rhetoric texts under 'variety in word choice') encourage writers to avoid repetition of this sort. The situation in Arabic is the opposite." Hatim (1997, pp. 164-165) states that repetition in Arabic can be either necessitated by the linguistic system (langue) or can include forms that have non-systemic function (parole); they are motivated by rhetorical functions of the text. Repetition in Arabic subtitling belongs to the linguistic system requirements, i.e., the langue, and thus it is a necessity for the cohesion of the text.

Opting for a non-condensation strategy in dealing with ellipsis in the STs is of interest here as repetition and substitution are used to translate ellipsis in the overwhelming majority of occurrences. This demonstrates that meeting the cohesiveness requirements of the TL discourse takes priority over compliance with the brevity requirement of subtitling. Explicitation seems to be a significant strategy to establish cohesion in Arabic subtitles. It triggers repetition in the TTs aiming at making what is implicit in the ST, which can be inferred by the ST audience, explicit in the subtitles to meet the cohesion condition of the TL. Based on the data discussed above, using cohesive devices in Arabic subtitles functions as an explicitation strategy in translation. 
The translation of substitution and ellipsis occurring in the STs will be discussed in detail below. Both the ST elements with a cohesive function and their counterparts in the TT are underlined. For reference purposes, the name of the film is given in brackets next to the ST. Back-translation of Arabic subtitles is also given between brackets. Subtitles are back translated using a mid-course between direct and idiomatic rendition as frequently as possible, with the aim of highlighting the changes occurring in the Arabic TTs.

\subsection{Translation of substitution}

Following Halliday and Hasan's classification of the three types of substitution, we will provide an analysis of examples that illustrates how translators dealt with the three types of substitution in the STs.

\subsubsection{Translation of nominal substitution}

Substitution is retained only once (14.29\%). The majority of nominal substitutions $(85.71 \%$, six out of seven occurrences) are translated into repetition. This seems to reflect a trend towards using repetition to fulfil the TL system preference and utilizing it as a safe strategy to ensure the message is clear with no misunderstanding or confusion. Translators made shifts by moving from the grammatical level (nominal substitution) in the ST to the lexical level (repetition) in the TT. This type of substitution is illustrated in the following example where the subtitle involves a shift into a repetition of رجل (man).

(7) ST: A. I thought I was a better judge of men.

B. You gave him credit for being one. (Possession)

TT: A. حسبت أنني بارع في الحكم على شخصية الرجال) (I thought I was skilful in judging men's character)

B. أنت مخطئ لأنك اعتبرته رجلاً (you are wrong because you considered him a man)

The nominal substitute one refers anaphorically in the original to the lexical entity mentioned before whereas the translator rendered it by repetition of the same lexical item instead of using substitution as the ST does to provide explicitness in the TT. Repetition provides a clear link between the two elements. Retaining substitution in the TT would be confusing to the audience if it is to be translated (you are wrong because you considered him one of them) as this may read as referring to one of a group in the sense of membership rather than quality as the actual subtitle successfully denotes. It would be even more awkward if the translator utilized واحداً (one in the sense of cardinal number). Unlike a shift into repetition, a direct translation in this case, by means of substitution, will produce non-cohesive text in the TL. 
In the example below two cohesive devices are used: nominal substitution ones and verbal substitution do. The latter will be discussed under 5.1 .2 below.

(8) ST: Iguanas don't swim, they are land animals.

These ones do. (Master and Commander)

TT: الإغوانا لا تسبح، إنها حيوانات أرضية (Iguanas don't swim, they are land animals)

هذه الحيوانات تسبح (These animals swim)

A direct translation of ones would not be recommended, as it would not produce a cohesive, coherent text. However, the translator did not repeat the substituted noun الإغوانا (Iguanas) in the TT but rather its hypernym or superordinate حيوانات (animals), making it as if it were a different species. The repetition of حيوانات (animals) does not contribute the cohesiveness to the TT. The translator could have opted for the repetition of the substituted noun الإغوانا (Iguanas) to fulfil both the cohesion and coherence of the TT: هذه الإغوانا تسبح (These Iguanas swim). Another option is to substitute the verb with تفعل (do) to become هذه الإغوانا تفعل هدهل (These Iguanas do). Moreover, with the use of هذه (these), omission would be a good option to have the TT read هذه هذه (The deictic هذه (Twim) or هذه تفعل (These do), thus producing the required condensation of the subtitles.

Nevertheless, a different approach can be seen here when nominal substitution is rendered as substitution rather than repetition:

(9) ST: What does your church do, Mr. Langdon?

That's right, you don't have one. (Angels and Demons)

TT: ماذا تفعل كنيستك، سيد لانغدون؟ (What does your church do, Mr. Langdon?)

هذا صحيح، ليس لديك واحدة (that's right, you don't have one)

This rendition is awkward Arabic style. The translator could have repeated the noun كنيسة (church) to make the $T T$ natural and cohesive. By relying on substitution in the $T T$, the translation provides the cardinal version of same lexical item of the ST device (rather than a similar word that denotes group membership أحد ) واحدة as the use of FEM) refers to a quantity (i.e., one, not two).

\footnotetext{
${ }^{1}$ kanīsah (church) is feminine in Arabic.
} 


\subsubsection{Translation of verbal substitution}

Translation by repetition is the most frequent approach used to translate verbal substitution, making up $75 \%$ (six out of eight) instances. Translation by nominal substitution accounts for $12.5 \%$ (one out of eight) instances. However, verbal substitution is used in one subtitle (12.5\%).

In the previous section on nominal substitution, we mentioned that example 8 also includes a case of verbal substitution.

(10) ST: Iguanas don't swim, they are land animals.

These ones do. (Master and Commander)

TT: الإغوانا لا تسبح، إنها حيوانات أرضية (Iguanas don't swim, they are land animals)

هذه الحيوانات تسبح (These animals swim)

The substitute do is translated by repeating the verb 'swim' in TT. While it was suggested earlier that ST nominal substitution can be rendered as ellipsis, verbal substitution, however, may not. The verb has to be repeated as in the TT and that is why we suggested in5.1.1 above the subtitle could be هذه تسبح (These swim). Another option is to substitute the verb in Arabic by تفعل which is the counterpart of 'do'. This is a common substitution in Arabic (see 2 above). The subtitling would be هذه الحيوانات تفعل (These animals do) or better هذه تفعل (These do). The latter is a condensed option, meeting the brevity condition of subtitling.

The example below shows that instead of using a direct rendition of the verbal substitute do to have a substitution in the TT as well, a shift is introduced by repeating the verb:

(11) ST: A. You forget I don't care what people think.

B. Yes, you do. (10 Things I Hate About You)

TT: A. إنك تنسين بأنني لا أكترث لرأي الناس (you forget that I do not care about people's opinion)

B. بل تكترثين (rather, you care)

This is an optional action that opts for more explicit rendition. The translation could use substitution as well to be بل تفعلين (rather, you do). 
This, nevertheless, cannot be done in the following example.

(12) ST: A. All women become like their mothers. That's their tragedy.

B. No man does, that's his. (Rumor Has It)

TT: A. تصبح كل النساء مثل أمهاتهن. هذه هي مأساتهن (All women become like their mothers. This is their tragedy)

B. لا رجل يصبح مثلهن، هذه هي مأساته (no man becomes like them, this is his tragedy)

The translator repeated the verb يصبح (to become) and هثل (like) with the pronominal reference هن (them FEM) to refer to 'mothers'. The translator's choice seems to be justified by the aim to make the meaning coherent through repetition since a direct translation, e.g. يفعل (do SING MASC) may denote action rather than the intended meaning of becoming as such. Repetition here facilitates comprehension as it provides a semantically less dense discourse. However, the use of the pronoun هن is ambiguous due to unclear reference on the one hand, i.e., whether it refers to 'women' or to 'mothers', and on the other hand it refers, in actual fact, to a man's own mother. Thus, the translator should have once again utilized repetition of أم (mother) as a cohesive device. Then the translation would read: لا رجل يصبح مثل أمه، هذه هي مأساته (no man becomes like his mother, this is his tragedy). The use of $h$ is in the ST is a case of nominal ellipsis, which will be discussed in example 19 below.

The shifts made in the examples above are justified in terms of serving the cohesive function of the $\mathrm{TL}$, reproducing the meaning of the ST and establishing coherence. There is a shift there resulting from altering the grammatical cohesive devise (the substitute does) into a lexical verb. In the following example, however, the translator retained substitution of the ST:

(13) ST: Hello, you've reached Arthur's machine. If you wish to leave a message, please do so after the tone (Michael Clayton)

TT: مرحبا، أنتم تتصلون بهاتف آرثر. إذا أردتم ترك رسالة فافعلوا ذلك بعد الزمور (Hello, you are calling Arthur's phone. If you want to leave a message, do that after the tone)

There is a verbal substitution here by using the verbal group افعلوا ذلك (do that) to translate do so. The demonstrative pronoun ذلك (that) serves the cohesiveness of the text by referring back to the phrase ترك رسالة which denotes the action of leaving a message. Repeating the verb of 'leave' and using a pronoun referring back to the 'message' is less cohesive in the TL, especially if it is in the same sentence: إذا أردتم ترك رسالة فاتركوها بعد الزمور (if you want to leave a message then leave it after the tone). 
In the example below, however, the translator rendered the verbal substitution does into a phrase made of a demonstrative supported by صحيح (true):

(14) ST: A. He moves fast.

B. Yes, he does. (Les Misérables)

TT: A. إنه يتحرك بسرعة (He moves fast)

B. هذا صحيح (that's right)

While rendering yes as صحيح (right) to indicate affirmation, the translator decided to convey the meaning of the verb does by using the proximal demonstrative (this) which refers anaphorically to the statement. This shift by a total change in the structure affects neither the ST meaning nor TT cohesion. The translator's attempt to fulfil cohesion in the TT is successful, given that subtitling aims at providing a condensed structure with yes encapsulated in the translation. The authors contend that this TT formulation is recommendable for such SL structures. It is a standard language closer to spoken variety. A more standard Arabic translation would have a rather formal register of a classical tone: أجل، إنه يفعل (yes, he does), or it would, if repeated, be longer, non-condensed subtitling أجل، إنه يتحرك بسرعة : (Yes, he moves fast).

\subsubsection{Translation of clausal substitution}

Three out of four occurrences of clausal substitution are rendered as clausal substitution (75\%) and one occurrence $(25 \%)$ as verbal substitution.

(15) ST: A. How was your sleep? Restful?

B. I would not say so, no (Australia)

TT: A. كيف كان نومك؟ مريحاً؟ (How was your sleep? Restful?)

B. الا يمكنني قول هذا، لا (I cannot say this)

The demonstrative used here, هذا (this), substitutes the statement made before to chain together information in the text. It provides the intended meaning and contributes to the cohesiveness of the TT. Translators tend to use demonstrative هذا (this) as a translation for so in the ST. Knowing that هذا (this) is a proximal demonstrative (Holes, 1995), it seems to be used in such cases in its nondemonstrative sense as a cohesive devise with a substitution function. 
In example 16, the translator used the direct translation strategy in dealing with the negative clausal substitution:

(16) ST: A. Is your decision to take a year off anything to do with the rumours about Jeff and his present leading lady?

B. Absolutely not. (Notting Hill)

TT: A. هل لقرارك بتوقيف عملك لعام علاقة بالإشاعات عن (جيف) وشريكته الحالية؟ Is your decision to stop your work a year a relation with the rumours about [Jeff] and his present partner FEM?)

B. بالتأكيد لا (certainly not)

Although it might be an unnecessarily longer version, one may repeat the same element using the demonstrative ذلك. The suggested response can be spelled out as بالتأكيد لا علاقة له بذل (certainly it has no relation to that). However, the translator opted not to, which is also cohesive in the TT, and at the same time the translation meets the brevity condition of subtitling. As this is a yes/no question, the direct translation approach conveys the message and establishes a cohesive TT. It is a standard language structure that is also used in spoken language (see also Badawi, 2012), something that is recommended for subtitling conversations. In subtitling, the verbal auditory channel becomes a verbal visual channel (Gottlieb, 1998, p. 245). Spoken dialogue in the ST is conveyed as a written text in the subtitles. This makes the language of subtitles much closer to the standard than the ST.

\subsection{Translation of Ellipsis}

In this section, representative examples of ellipsis will be analysed to illustrate how this cohesive device is translated in Arabic subtitles.

\subsubsection{Translation of nominal ellipsis}

Nominal substitution is used to translate $50 \%$ of nominal ellipsis (three out of six) and repetition is used for $33.33 \%$ of nominal ellipsis (two out of six), whereas there is a shift into reference in $16.6 \%$ of occurrences (one out of six). 
(17) ST: Isn't that Dr. Wolfe's assistant?

Was (Possession)

TT: أليس هذا مساعد الدكتور وولف؟ (Isn't this Dr. Wolfe's assistant?)

كان كذلك (he was as such)

Here, the translator opted for the addition strategy to cater for the cohesiveness of the TT, as using the verb كان (was) only would not be enough to establish cohesion. The added prepositional phrase is composed of the particle of simile (كاف التشبيه) and the demonstrative ذلك (that) to achieve TT cohesion. The demonstrative is assisted by the simile particle to provide a substitute by the anaphoric reference to the whole previous statement and thus helps the reader retrieve the identity of the item stated earlier.

In example 18, the translator opted for addition using the word واحدة (one FEM) as a counterpart for the ellipted element in the ST.

(18) ST: A. There is gonna be a better way.

B. No, if there is, I don't know (Flicka)

TT: A. بالتأكيد ثمة طريقة أفضل (sure there is a better way)

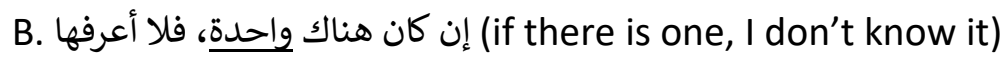

The ellipsis in the ST is a feature of the SL discourse, which cannot be applicable to TL in this case, because of the grammatical requirements of the Arabic sentence to have a noun. The Arabic sentence in B cannot be informative if one of its parts is elided without a pointer. In this example, واحدة (one as a cardinal) is added to serve as a substitution in the TT. However, the added word results in an awkward non-cohesive translation as it refers to a quantity, not quality, i.e. without providing the preference noun (comparison). The translator should have used repetition to ensure the text has the right reference and natural style thus helping the audience understand it with ease. If the nominal group 'better way' is repeated in the TT, there can be two more options that fulfil the cohesiveness of the TT. The suggested translations would be either إن كان هناك واحدة أفضل فلا أعرفها (if there is a better one, I don't know it) or إن كان هناك طريقة أفضل فلا أعرفها (if there is a better way, I don't know it). Although both versions are longer, they provide better translations in terms of cohesiveness. 
We already discussed the example below as a case of verbal substitution (see example 12 above). It is also cited here as it features a case of nominal ellipsis as well:

(19) ST: A. All women become like their mothers. That's their tragedy.

B. No man does, that's his. (Rumor Has It)

TT: A. تصبح كل النساء مثل أمهاتهن. هذه هي مأساتهن (All women become like their mothers. This is their tragedy)

B. لا رجل يصبح مثلهن، هذه هي مأساته (no man becomes like them, this is his tragedy)

The noun tragedy is elided in that's his $\varnothing$. The translator, however, repeated the noun مأساة(tragedy). The structure of the English sentence allows such omission and the sentence is still meaningful. This is a feature of spoken discourse of the SL which is inapplicable to the TL as an enclitic pronoun in Arabic (corresponding to his here) is a bound morpheme that needs a noun or a verb to attach to. Rather, repetition is obligatory in order to maintain the cohesiveness of the TT.

Similarly, in the example below, the translator made a shift by repeating the noun which is omitted in the second part of the ST:

(20) ST: We need three messages ...

What if I don't get three? (Echelon Conspiracy)

TT: نحتاج إلى ثلاث رسائل (We need three messages)

وماذا إذا لم أحصل على ثلاث رسائل؟؟ (And what if I don't get three letters?)

An Arabic sentence does not allow the deletion of the countable noun (messages), what is termed in Arabic grammar التمييز (adverb of specification), after an indefinite noun. It is necessary to specify the element being modified by the numerative and make it clear what item is being discussed (Al-Suyoty, 1978, p. 262). This is an obligatory operation and applies to the first part of the TT only. However, it is optional in the second part of the TT since it is stated in the first part of the text or known for the addressee or understood from the context. The ellipted version would read (And what if I don't get three?) (see Al-Sāmār'iy, 2007, p. 77). Shifting from ellipsis into repetition is successful though, because repetition serves the cohesion of the TT by reminding the audience of the previously mentioned lexical item. 
(21) ST: A. I know what you want, Lara

B. Oh, I doubt it

A. Another life with your father. A second chance.

It will be within my power to give (Lara Croft: Tomb Raider)

TT: A. أعلم ماذا تريدين يا لارا (I know what you want Lara)

B. أشك بذلك (I doubt that)

A. حياة أخرى مع والدك. فرصة أخرى (Another life with your father. Another chance)

سأتمتع بالسلطة لمنحك إياها

There is an ellipsis here in it will be within my power to give $\varnothing$. The translator resorted to addition to function as a reference and produce a cohesive TT. S/he utilized the pronoun إياها (it) which refers anaphorically to the noun فرصة (chance) stated before. Without such addition, the translation would lack cohesion (and ultimately coherence) and would therefore not be successful.

\subsubsection{Translation of verbal ellipsis}

A shift of verbal ellipsis to repetition accounts for $66.67 \%$ of its occurrences (four out of six), and verbal substitution is used to render $33.33 \%$ of occurrences (two out of six).

(22) ST: Reed I trust. Peterson I don't (Echelon Conspiracy)

TT: أثق بـ (ريد) ولكنني لا أثق بـ(بيترسون) (I trust [Reed], but I don't trust [Peterson])

In this example, the ST verb is elided in the second part of the line. In the subtitles, a shift occurred whereby the main verb أثق (trust) is repeated. To enhance the cohesiveness of the TT, adversative conjunction لكن (but) and the conjunctive particle و (and) are also added in the TT. The cohesion of the TT is achieved through these two shifts, i.e., repetition to specify the verb and make it explicit to the addressee, and the adversative conjunction that links the two sentences and signals the meaning of concession (استدراك) to the preceding statement. 
(23) ST: I thought you were dead

$$
\text { Could (Gladiator) }
$$

TT: خلتك مت (I thought you died)

كدت أموت (I almost died)

For the verb أموت (to die) in this example, ellipsis in the TT is not a choice for it occurred in a response. It would be possible if it was in the same sentence. A possible Arabic translation of the modal verb could alone does not produce the intended meaning. The verb used here $\mathbf{}$ belongs to the verbs of appropinquation (أفعال المقارية), denoting an imminent event. Ellipsis in the reply cannot be used since, unlike example 5, the two occurrences are not within the same sentence (see also Hassan, 1979, p. 219). Repetition of the verb is necessary for the cohesive function of the text by having a clear focus on the intended meaning.

(24) ST: I thought you are leaving tomorrow?

I was. (Notting Hill)

TT: اعتقدت أنك ستسافرين غداً (I thought you will travel tomorrow)

كنت سأفعل (I was about to do)

In the ST the verb is elided: I was $\varnothing$. The translator opted for the addition strategy, i.e., adding the verb أفعل (I do) as a verb of action to substitute أسافر (to travel) stated in the previously mentioned clause. Not repeating or substituting the verb would produce a non-cohesive text, or it would be perceived as incomplete sentence or a false start. 


\subsubsection{Translation of clausal ellipsis}

The kind of clausal ellipsis found in our data is the one that involves interrogative clauses which are categorized by Halliday and Hasan (1976, pp. 206-215) under rejoinders to seek confirmation and have the form of interrogative clauses with propositional ellipsis, i.e., question tags at the end of a declarative or imperative clause. All occurrences of clausal ellipsis except one are translated into tag questions that involve substitution to refer to the previous elliptical statement in the ST.

(25) ST: A. My daughter Jane is a splendid dancer, is she not?

\section{B. She is indeed (Pride and Prejudice)}

TT: A. ابنتي (جاين) مذهلة في الرقص، أليس كذلك؟ (My daughter [Jane] is an amazing dancer, is it not as such?)

B. بالتأكيد (certainly)

In this example, there are two cases of clausal ellipsis occurring in rejoinders where the complement is elided. In the first one, the translator adopted a direct translation by a fixed Arabic short interrogative structure أليس كذلك (is it not as such). This is a formal correspondence approach, a procedure to preserve the rhetorical purpose of assertion. The TT features a substitution of the previous clause although according to traditional Arabic grammar, كذلك (as such) is a prepositional phrase that refers to an omitted phrase indicating the previous clause. The interpretation of the first example can be ابنتي (جاين) مذهلة في الرقص، أليست هي مذهلة في الرقص؟ (My daughter [Jane] is an amazing dancer, is she not an amazing dancer?). The TL tag question deletes she and is of the ST, making it a more general question that applies to any kind of statement. The translation could abandon the ST structure and merge both parts (the statement and the tag question) into one interrogative in Arabic that is shorter and more natural: أليست ابنتي (جاين) مذهلة في الرقص؟ (Is my daughter [Jane] not an amazing dancer?).

The second case of clausal ellipsis occurs in the response she is indeed. Whereas an affirmative response of (yes) could be given, the translation provided instead an Arabic counterpart of 'indeed' which is part of an elliptical sentence. The TT deletes she is and involves ellipsis of the clause بي مذهلة في الرقص where the full response is بالتأكيد هي مذهلة في الرقص (Indeed she is an amazing dancer). What helped in having ellipsis here, creating successful communication, is the information that can be retrieved from the previous line (index). It is worth noting that this is one case (of only two) of ellipsis used in the subtitles examined here (see example 28). However, this is optional as the translation could have given a full sentence, but for brevity and condensity, ellipses is opted for.

In the two examples below, the questions in the STs are rejoinders to the statements that aim at providing the rhetorical purpose of assertion or provide confirmation. Subtitles translated the tag 
questions as أليس كذلك (is it not as such) which is the most common form of translation for tag questions used by translators, whereas صحيح (true/right) in example 28 below is a less common translation:

(26) ST: She gave up her life, didn't she? (Possession)

TT: لقد تخلت عن حياتها، أليس كذلك؟ (She gave up her life, is it not as such?)

(27) ST: This is a pleasant fiction, isn't it? (Gladiator)

TT: هذا تخيل جميل، أليس كذلك؟ (This is a beautiful imagination, is it not as such?)

The function of tag questions is to keep a channel of communication open (Halliday \& Hasan, 1976, p. 207). The unified translation using the interrogative structure contributes to the cohesiveness of the TTs, conveys the meanings intended by the questions and adds an element of assertion, which. However, adopting one interrogative structure in TTs to correspond to the function of two different tag questions in the STs results in levelling out the TTs, i.e., providing one uniform translation for all kinds of tag questions.

(28) ST: You're looking rather well, Smith. Been enjoying yourself, have you? (The New World)

TT: تبدو بخير يا سميث، كنت تستمتع بوقتك، صحيح؟) (You look well, Smith. You have been enjoying your time, right?)

Here, the operator been and the verb in the progressive enjoying are omitted in the ST tag question. The subtitle corresponds to that feature and achieves the cohesive function in the TL. The word صحيح (true/right) is used as an interrogative element to compensate for not having a corresponding TL structure for the English tag question, referring anaphorically to what has been said earlier. This is, then, another case of clausal ellipsis in the TT with the full sentence being أصحيح كنت تستمتع بوقتك؟ (Is it right that you have been enjoying your time?) (see example 25). The subtitle lacks an interrogative particle such as hamza. However, it is deleted due to frequent use, which is closer to spoken variety. We believe that this approach makes such TL structure recommended for the subtitling of small talk and casual conversation. The translation here has the merit of being shorter than the tag question form أليس كذلك (is it not as such) used in other subtitles.

The examples of clausal ellipsis in English are all tag questions, which is a grammatical structure specific to the SL. Such structure is originally uncommon or almost non-existent in the TL. ${ }^{2}$ This is rather modern usage in Arabic, mainly as a by-product of translation and in response to SL formulation, by providing a calque translation. However, in Arabic it can fall under استفهام التقرير

\footnotetext{
${ }^{2}$ In the Arabic premodern subcorpus, with more than 9 million words, there is only one occurrence of ألبس كذلك (is it not as such MASC) and only two of أليست كذللك (is it not as such FEM). See http:// arabicorpus.byu.edu
} 
(assertion interrogatives), which is about inviting the addressee to acknowledge and recognize what the speaker believes in (Al-Zarkašhy, n.d., vol. 2, p. 331; see also Saḥraoui, 2005, p. 163).

While the examples are translatable, they do not reflect the same rhetorical purpose as the ones in the SL. Thus, translators opted for formal correspondence to preserve the rhetorical purpose of assertion.

\section{Conclusions}

The paper has examined how substitution and ellipsis in English texts are translated into Arabic subtitles. The study findings show that through translation, the use of cohesive devices in subtitles departs from that in the STs. The analysis provided in the present paper demonstrates that translators altered most of ST cohesive ties and maintained few of them. Shifts are successful in the overwhelming majority of the cases discussed, i.e., they achieve the cohesive function of the TT and do not affect the meaning of ST. As Arabic prefers explicit relations (see Johnstone, 1991) translations tend to state clearly the ties by mostly changing ellipsis and substitution into repetition, moving from grammatical into lexical cohesion. It is worth nothing that although some cases would be cohesive in Arabic using ellipsis or substitution, translators used repetition instead.

Repetition as a cohesive device in Arabic is pervasive in the translation of nominal substitution, verbal substitution, nominal ellipsis, and verbal ellipsis. Repetition is cohesive (Johnstone, 1991, p. 108), and it also enhances the readability of the text (De Linde \& Kay, 1999, pp. 28-31)

While substitution is used to translate substitution, mainly clausal substitutions, it is also used to recover ellipsis. The study has found that only two cases of ellipsis are translated as ellipsis in the subtitles, which seems to be a product of focusing on one element in the elliptical sentence rather than providing a yes/no response. Otherwise, ellipsis is mainly rendered by means of repetition and substitution.

Using ellipsis and clausal substitution is in line with the brevity principle in subtitling. However, the translation of cohesive devices into repetition is against this principle, giving priority to TT cohesion and coherence. When ellipsis is recovered and translated into repetition, it runs counter to the condensation requirement of subtitling; however, cohesion is important in processing and understanding the TT and helps in making it coherent for the target audience.

Addition as a translation strategy of explicitation is opted for to serve as a cohesive tie in dealing with ellipsis, i.e., lexical elements are added in the translation to provide repetition, substitution and reference as cohesive devices. We can see that the deployment of these three devices in Arabic subtitles serves as some kind of explicitation. Moreover, in some cases, translators' approach to use one formulation in Arabic tend to level out the TTs. 


\section{References}

Al-Jurjāny, A. (2004). Dalā'il Al-i'jāz [Signs of inimitability]. Beirut: Dār Al-Jīl.

Al-Sakkāky, Y. (1987). Miftāḥ Al-'ulūm [Key to scholarship] (2nd edition). Beirut: Dār Al-Kutub Al'ilmiyah.

Al-Sāmār'iy, F. (2007). Al-jumlah Al-'arabiyah, ta'līfuhā wa 'aqsāmuhā [The Arabic sentence: its structure and parts]. Amman: Dār Al-fikr.

Al-Suyoțy, J. (1978). Al-itqān fy 'ulum al-qur'ān [Mastering Quranic scholarship]. Cairo: Dār Al-turāṭ.

Al-Zarkašy, B. M. A. (n.d.). Al-burhān fy 'ulūm Al-qur'ān [The evidence in Quranic scholarship]. Cairo: Dār Al-turāt.

Badawi, A. M. (2012). Mustawayāt Al-'arabiyah Al-mu'āșirah fy mișr [Levels of contemporary Arabic in Egypt]. Cairo: Dār Al-Salām Publishing.

Baker, M. (1992). In Other words. London \& New York: Routledge.

Bakker, M., Koster, C., \& Van Leuven-Zwart, K. (1998). Shifts in translation. In M. Baker, (Ed.), Routledge encyclopedia of translation (pp. 226-231). London \& New York: Routledge.

Bevan, T. et al. (Producers), \& Wright, J. (Director). (2005). Pride and prejudice [Motion picture]. UK: Universal Pictures et al.

Catford, J. (1965). A linguistic theory of translation. London: Oxford University Press.

Chiaro, D. (2009). Issues in audiovisual translation. In J. Munday (Ed.), The Routledge companion to translation studies (pp. 141-165). London \& New York: Routledge.

Cintas, J. D., \& Remael, A. (2007). Audiovisual translation: Subtitling. Manchester: St. Jerome.

Cosgrove, B. et al. (Producers), \& Reiner, R. (Director). (2005). Rumor has it [Motion picture]. USA: Warner Bros et al.

De Beaugrande, R. (1980). Text, discourse and process: Towards a multidisciplinary science of texts. Norwood, N.J.: Ablex.

De Linde, Z., \& Kay, N. (1999). The semiotics of subtitling. Manchester: St. Jerome.

Goldwyn, S. Jr. et al. (Producers), \& Weir, P. (Director). (2003). Master and commander [Motion picture]. USA: 20th Century Fox et al.

Gordon, L. et al. (Producers), \& West, S. (Director). (2001.) Lara Croft: Tomb Raider [Motion picture]. USA: Paramount Pictures et al.

Gottlieb, H. (1998). Subtitling. In M. Baker, (Ed.), Routledge encyclopedia of translation (pp. 244248). London \& New York: Routledge.

Grazer, B. et al. (Producers), \& Howard, R. (Director). (2009). Angels and demons [Motion picture]. USA: Columbia Pictures et al.

Green, S. et al. (Producers) \& Malick, T. (Director). (2005). The new world [Motion picture]. USA: First Foot Films et al.

Halliday, M., \& Hasan, R. (1976). Cohesion in English. London: Longman.

Halloran, K. et al. (Producers), \& Mayer, M. (Director). (2006). Flicka [Motion picture]. USA: Fox 2000 Pictures et al.

Hammudah, Ṭ. (1998). Zahirat Al-had hf fy Al-dars Al-lugaawiy [Phenomenon of ellipsis in the study of lingusitics]. Alexandria: Al-dār Al-Jami iyyah.

Ḥassan, T. (1979). Al-luġah Al-'arabiyah: ma'nāhā wa mabnāhā [The Arabic language: its semantics and structures]. Cairo: al-Hay'ah al-Mașriyyah al-'āmmah lil-Kitāb.

Hatim, B. (1997). Communication across cultures. Exeter University Press.

Holes, C. (1995). Modern Arabic: Structures, functions and varieties. London: Longman. 
Johnstone, B. (1991). Repetition in Arabic discourse: Paradigms, syntagms and the ecology of language. John Benjamins. Retrieved from ProQuest Ebook Central, http://ebookcentral.proquest.com/lib/aus-ebooks/detail.action?docID=740285.

Kenworthy, D. et al. (Producers), \& Michell, R. (Director). (1999). Notting Hill [Motion picture]. UK: Polygram Filmed Entertainment et al.

Lazar, A. (Producer), \& Junger, G. (Director). (1999). 10 Things I hate about you [Motion picture]. USA: Touchstone Pictures et al.

Levinson, B. et al. (Producers), \& LaBute, N. (Director). (2002). Possession [Motion picture]. USA: Warner Bros et al.

Leyvimam, A. et al. (Producers), \& Marcks, G. (Director). (2009). Echelon conspiracy [Motion picture]. USA: Dark Castle Entertainment et al.

Luhrmann, B. et al. (Producers), \& Luhrmann, B. (Director). (2008). Australia [Motion picture]. Australia: 20th Century Fox et al.

Pollack, S. et al. (Producers), \& Gilroy, T. (Director). (2007). Michael Clayton [Motion picture]. USA: Section Eight et al.

Radclyffe, S. et al. (Producers), \& August, B. (Director). (1998). Les Misérables [Motion picture]. UK, Germany and USA: Mandalay Entertainment et al.

Saḥraoui, M. (2005). Al-tadāwiliya 'inda Al-'ulamā' Al-'arab [Pragmatics from the perspective of classical Arab scholars]. Beirut: Dār Al-țali 'ah.

Wick, D. et al. (Producers), \& Scott, R. (Director). (2000). Gladiator [Motion picture]. UK and USA: Universal Pictures et al. 